\title{
Pervaporation dehydration of ethanol-water mixture using crosslinked poly(vinyl alcohol) membranes
}

- Tran Le Hai

- Vuu Ngoc Duy Minh

- Hoang Minh Quan

- Nguyen Thi Nguyen

- Mai Thanh Phong*

Ho Chi Minh City University of Technology, VNU-HCM

(Manuscript Received on October 19th, 2016, Manuscript Revised November 28th, 2016)

\begin{abstract}
Crosslinked poly(vinyl alcohol) (PVA) membrane was changed via crosslinking composite membranes were synthesized by casting selective crosslinked PVA films on the polyacrylonitrile (PAN) porous substrates. The PVA films were prepared by in-situ crosslinking technique using four different crosslinking agents, such as glutaraldehyde, fumaric acid, maleic acid and malic acid. The separation performance in terms of permeation flux and separation factor of prepared membranes were evaluated for pervaporation dehydration of ethanol/water mixture of $80 / 20 \mathrm{wt} \%$ at $60{ }^{\circ} \mathrm{C}$. The prepared membranes were also characterized by FTIR, SEM, swelling and sessile drop contact angle measurements. It was found that the chemical structure of the PVA reaction. The physicochemical properties (hydrophilicity and swelling degree) and separation performance of the prepared membranes were affected by the chemical structures of the crosslinking agents. Furthermore, there was a trade-off between permeation flux and selectivity of the resulting membranes. When the flux increased, the separation factor decreased. The results of this study contributed to enrich the data of the crosslinking reaction of PVA membranes, and expected to help researcher in suitable choosing crosslinking agent for producing pervaporation PVA membrane for dehydration of ethanol solutions.
\end{abstract}

Keywords: Poly (vinyl alcohol), crosslinking, membrane, pervaporation, dehydration.

\section{INTRODUCTION}

Nowadays, pervaporation has been gaining much attention as an effective membrane technique for separating heat sensitive; close boiling and azeotropic mixtures due to its low energy consumption, benign operating conditions, no emission to the environment, no involvement of additional species into the feed stream and simplicity of the process $[1,3]$. Polymer based pervaporation membranes were 
the most widely used for dehydration of ethanol/water mixtures because of their inexpensive fabrication and operation costs. The commercialized pervaporation membrane employed in ethanol/water separation is PERVAP membrane, which is formed by Sulzer (Germany). It is a composite membrane with a PVA active layer coated on a polyacrylonitrile (PAN) porous support membrane. The main advantage of the composite membrane is the higher permeation flux, stability and good selectivity as compared to traditional one-layer membrane [2,3].

So far, poly(vinyl alcohol) (PVA) has been attracting for development of pervaporation membranes for ethanol dehydration [1-8]. It is due to the inherent hydrophilicity, excellent thermal, mechanical, chemical stability and good film-forming ability of PVA. However, because of the high hydrophilicity, the PVA films is not stable in aqueous solutions, leading to low separation performance of the derived membranes. Therefore, PVA membranes should be modified to offer long-term durability in a pervaporation process. Some techniques usually used for modifying PVA membrane are heating, grafting, crosslinking, irradiating and blending [2]. Among them, crosslinking is more efficient because the physicochemical properties and separation performance of the prepared membranes are easily controlled by varying the crosslinking agents, crosslinker concentration and reaction conditions. PVA membrane could crosslink by dicarboxylic acids, dialdehydes, and alkoxysilanes [2,3]. Many crosslinkers such as fumaric acid, maleic acid and glutaraldehyde are investigated for crosslinking PVA membrane. Previous studies showed that glutaraldehyde reacted with PVA at ambient temperature to produce crosslinking linkages [2-
6], but the PVA crosslinked with dicarboxylic acids need higher temperature $\left(>100 \quad{ }^{\circ} \mathrm{C}\right)$ $[2,3,7,8]$. However, to our knowledge, the effect of different chemical structures of crosslinking agent on the physicochemical properties and separation performance of modified membrane was not concerned sufficiently. In this study, we developed the composite membranes by casting a crosslinked PVA layer on a PAN porous substrate. The PAN porous could suppress the swelling of the PVA selective film at the interface and thus retain the dense skin. Accordingly, the high permeation flux and good selectivity as well as the durability of the pervaporation membranes could be achieved [13,8]. In-situ crosslinking technique was employed to prepared crosslinked PVA selective layer using four different crosslinking agents such as glutaraldehyde (GA), fumaric acid, maleic acid and malic acid in the presence of $\mathrm{HCl}$ as catalyst. The fumaric and maleic acids had the same number of carbon atoms and also the carbon double bond. The difference of the two acids was that the fumaric acid had the trans configuration while the maleic acid owned the cis configuration. The trans structure of fumaric acid was expected to much more pack the polymer chain and give better selectivity for the modified membrane. The malic acid had an additional hydroxyl group which was hypothesized to provide more hydrophilic property for the crosslinked membrane, whereas GA with the reduced oxygen content was looked forward to produce the tightest crosslinked membrane. The effects of crosslinker's chemical structure on the physicochemical properties (i.e., chemical structure, hydrophilicity and swelling degree) of the crosslinked membranes were characterized using FTIR, SEM, swelling and sessile drop contact angle measurements. The

\section{Trang 98}


separation performance of the prepared membrane in terms of flux and separation factor was evaluated for pervaporation dehydration of the ethanol/water mixture of $80 / 20(w t \%)$ at 60 ${ }^{\circ} \mathrm{C}$.

\section{EXPERIMENTAL}

\subsection{Membrane preparation}

PVA $\left(\mathrm{M}_{\mathrm{w}}\right.$ 146-186 kDa, 99\%, Sigma $)$ solutions with the concentration of $10 \mathrm{wt} \%$ were prepared by dissolving PVA in deionized (DI) water at $90{ }^{\circ} \mathrm{C}$ under agitation for $6 \mathrm{~h}$. Next, PVA solution was cooled to room temperature and the crosslinkers with the concentration of 5 wt $\%$ per weight of PVA was added under continuous stirring for $24 \mathrm{~h}$. Four crosslinkers used in this study were glutaraldehyde (GA, $25 \%$ in water), fumaric acid, maleic acid and malic acid (>98\%, Sigma, USA). The $2 \mathrm{M} \mathrm{HCl}$ solution as catalyst was subsequently added under vigorous stirring for $3 \mathrm{~h}$ to produce PVA casting solution. Then the resulting solution was degassed before casting. The composite membranes were prepared by casting PVA aqueous solution on the PAN support membranes (PAN200, Ultura, USA) by using a casting knife with a constant gap of $70 \mu \mathrm{m}$. The resulting membranes were dried at room temperature for $48 \mathrm{~h}$. After that, the prepared membranes were crosslinked at elevated temperature in $2 \mathrm{~h}$ at $120{ }^{\circ} \mathrm{C}$ for the three dicarboxylic acids $[2,3,7]$, while the ambient temperature $\left(30{ }^{\circ} \mathrm{C}\right)$ was fixed for GA [2-6]. Finally, the derived membranes were immersed in $80 \mathrm{wt} \%$ ethanol solution for $3 \mathrm{~h}$ and dried at room temperature for $24 \mathrm{~h}$ before pervaporation tests.

Table 1. The characteristics of original PAN200 support substrate

\begin{tabular}{|c|c|c|c|c|c|}
\hline \multicolumn{3}{|c|}{ Membrane } & \multicolumn{3}{c|}{ Recommended operating limits } \\
\hline Material & $\begin{array}{c}\text { Total thickness }{ }^{1} \\
(\mu \mathrm{m})\end{array}$ & $\begin{array}{c}\text { Nominal } \mathrm{MWCO}^{2} \\
(\mathrm{Da})\end{array}$ & $\begin{array}{c}\mathrm{pH} \\
\text { range }\end{array}$ & $\begin{array}{c}\text { Pressure } \\
\text { range }(\text { bar })\end{array}$ & $\begin{array}{c}\text { Temperature } \\
\text { range }\left({ }^{\circ} \mathrm{C}\right)\end{array}$ \\
\hline PAN & 165 & 20,000 & $2-10$ & $1-10$ & $20-80$ \\
\hline
\end{tabular}

${ }^{1}$ Including the non-woven support of thickness approximately $100 \mu \mathrm{m}$

${ }^{2}$ Based on above $70 \%$ rejection of PEG

Table 2. Chemical formula and structure of investigated crosslinking agents

\begin{tabular}{|l|c|c|c|}
\hline Crosslinker & Chemical formula & Chemical structure & $\mathrm{M}_{\mathrm{w}}(\mathrm{g} / \mathrm{mol})$ \\
\hline Glutaraldehyde & $\mathrm{C}_{5} \mathrm{H}_{8} \mathrm{O}_{2}$ & $\mathrm{OHC}\left(\mathrm{CH}_{2}\right)_{3} \mathrm{CHO}$ & 100.12 \\
\hline Fumaric acid & $\mathrm{C}_{4} \mathrm{H}_{4} \mathrm{O}_{4}$ & Trans $-\mathrm{HO}_{2} \mathrm{CCH}=\mathrm{CHCO}_{2} \mathrm{H}$ & 116.07 \\
\hline Maleic acid & $\mathrm{C}_{4} \mathrm{H}_{4} \mathrm{O}_{4}$ & $\mathrm{Cis}-\mathrm{HO}_{2} \mathrm{CCH}=\mathrm{CHCO}_{2} \mathrm{H}$ & 116.07 \\
\hline Malic acid & $\mathrm{C}_{4} \mathrm{H}_{6} \mathrm{O}_{5}$ & $\mathrm{HO}_{2} \mathrm{CCH}_{2} \mathrm{CH}(\mathrm{OH}) \mathrm{CO}_{2} \mathrm{H}$ & 134.09 \\
\hline
\end{tabular}




\subsection{Membrane characterization}

The surface and thickness of the PVA selective layers was determined from SEM images by using Scanning Electron Microscopy (S4800, FE-SEM) and digital micrometer (accuracy $\pm 1 \mu \mathrm{m}$, Series 293, Mitutoyo). The chemical structure of the membranes was characterized using ATR-FTIR spectroscopy. The hydrophilicity of the membrane surfaces was investigated using sessile drop water contact angle measurement.

\subsection{Swelling experiments}

The pieces of dried membranes with the dimension of $3 \times 3 \mathrm{~cm}$ were immersed in both water and ethanol/water solution of $80 / 20 \mathrm{wt} \%$ at $30{ }^{\circ} \mathrm{C}$ for $48 \mathrm{~h}$ to reach an equilibrium swelling. The swollen membranes were wiped carefully using tissue paper for removing residual solution on the membrane surfaces. Then, the swollen membranes were weighted by a mass balance (accuracy $\pm 0.0001 \mathrm{~g}$ ). The degree of swelling was defined as

$$
S D(\%)=\frac{W_{S}-W_{D}}{W_{D}} \times 100 \%
$$

Wherein, $\mathrm{W}_{\mathrm{S}}(\mathrm{g})$ and $\mathrm{W}_{\mathrm{D}}(\mathrm{g})$ were the mass of the swollen membrane and the mass of the dried membrane, respectively. The data of swelling degree were collected from four replicate experiments.

\subsection{Pervaporation performance}

The separation performance of prepared membranes was investigated for ethanol/water mixture of $80 / 20 \mathrm{wt} \%$, using a lab scale pervaporation unit. The schematic diagram of the pervaporation setup was illustrated in Figure 1. A module membrane designed with the membrane area of $19 \mathrm{~cm}^{2}$ with a channel height of $2 \mathrm{~mm}$. The feed solution was circulated from the feed tank through the membrane cell with a flow rate of $90 \mathrm{~L} / \mathrm{h}$ by a pump. The temperature of the feed solution was maintained at $60 \pm 1{ }^{\circ} \mathrm{C}$ by a laboratory recirculating heater. The pressure of the feed side was at atmosphere pressure and the pressure on the permeate side was maintained lower than 1 mbar by using a vacuum pump (Robinair, USA). The separation process was conducted for $2 \mathrm{~h}$, and the permeate vapor was condensed in a cold trap by a laboratory chiller and heat exchanger using pure ethanol liquid $\left(-15{ }^{\circ} \mathrm{C} \div-20{ }^{\circ} \mathrm{C}\right)$. The collected permeate was weighed using a mass balance (accuracy $\pm 0.0001 \mathrm{~g}$ ) for determining the permeation flux. The permeation flux $(\mathrm{J})$ was determined using the following equation

$$
J=Q /(A t)
$$

Where, $\mathrm{Q}(\mathrm{g}), \mathrm{A}\left(\mathrm{m}^{2}\right)$ and $\mathrm{t}(\mathrm{h})$ represented the weight of permeate, effective membrane area and the operation time, respectively.

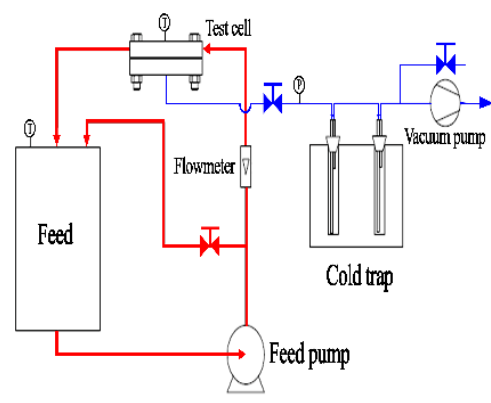

Figure 1. The schematic diagram of the lab scale pervaporation unit

The composition of permeated product was specified by measuring the refractive indices with a digital differential refractometer (Reichert, AMETEK GmbH, Germany) with the aid of a calibration curve for ethanol/water mixture prepared using known quantities of the two components. The refractometry 
measurement was carried out at $25{ }^{\circ} \mathrm{C}$. The separation factor $(\alpha)$ was defined as

$$
\alpha=\frac{y_{W} / y_{E t O H}}{x_{W} / x_{E t O H}}
$$

Where, $\mathrm{x}_{\mathrm{w}}, \mathrm{x}_{\mathrm{EtOH}}, \mathrm{y}_{\mathrm{w}}$, $\mathrm{y}_{\mathrm{EtOH}}$ were the weight fractions of water and ethanol in the feed and permeate side, respectively. The data of permeation flux and separation factor reported in this work were based on the average of four experimental runs.

The pervaporation separation index (PSI) of the membranes was calculated by the following equation

$$
P S I=J \times \propto
$$

\section{RESULTS AND DISCUSSION}

\subsection{Physicochemical properties of the} crosslinked PVA membranes

Four crosslinkers including GA, fumaric acid, maleic acid and malic acid with different chemical structures were investigated for modifying PVA composite membrane. The FTIR spectra of virgin PVA and crosslinked PVA composite membranes were shown in

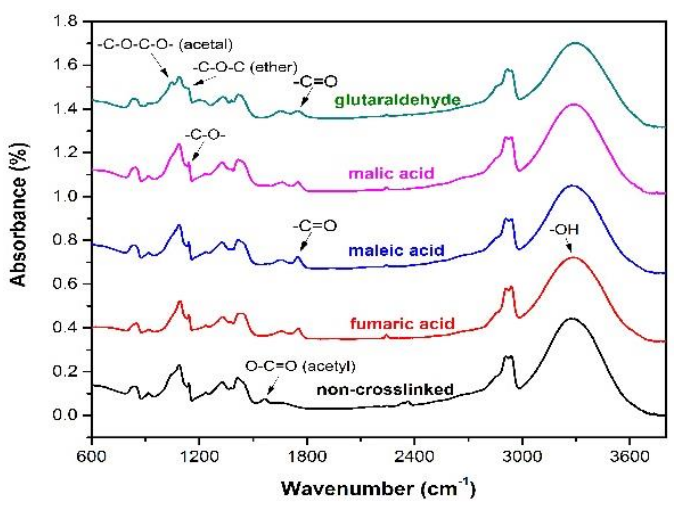

Figure 2. FTIR spectra of non-crosslinked and crosslinked PVA membranes
Figure 2. For the non-modified membrane, the broad peak at $3000-3600 \mathrm{~cm}^{-1}$ attributed to the hydroxyl group and the peak at $1578 \mathrm{~cm}^{-1}$ was characteristic of acetate group of PVA. For the crosslinked membranes, the intensity of the broad peak at $3000-3600 \mathrm{~cm}^{-1}$ was reduced and the peak at $1578 \mathrm{~cm}^{-1}$ was disappeared. In the spectra of the membrane crosslinked by three dicarboxylic acids, a new small peak at 1725 $\mathrm{cm}^{-1}$ attributed to the ester group was observed as compared to the non-crosslinked membrane [7]. Whereas, the PVA membrane crosslinked with GA exhibited the stretch of $1050 \mathrm{~cm}^{-1}$ and $1140 \mathrm{~cm}^{-1}$ for acetal and ether linkages [4-6]. The changes in the FTIR spectra implied that the chemical structure of the PVA membrane was altered by the crosslinking linkages compared to the plain PVA membrane.

Figure 3 showed the contact angle and swelling degree of the prepared membranes. The contact angle, indicating the hydrophilicity of the crosslinked membrane surfaces was between $50^{\circ}$ and $57^{\circ}$. It indicated that the hydrophilicity of crosslinked membranes was lower than that of non-crosslinked membrane.

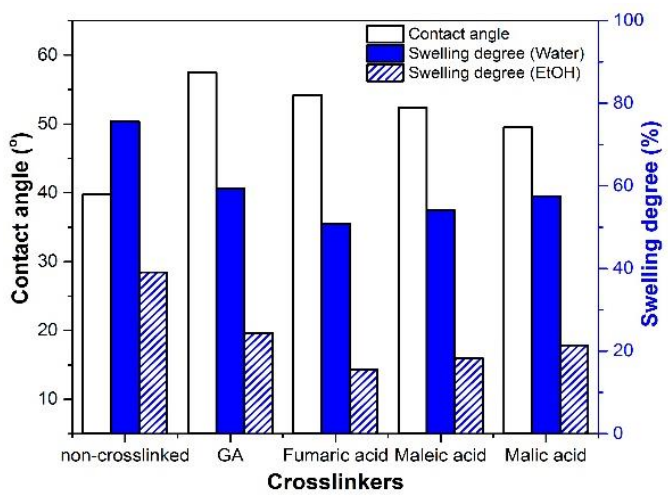

Figure 3. Hydrophilicity and swelling degree of prepared membranes 

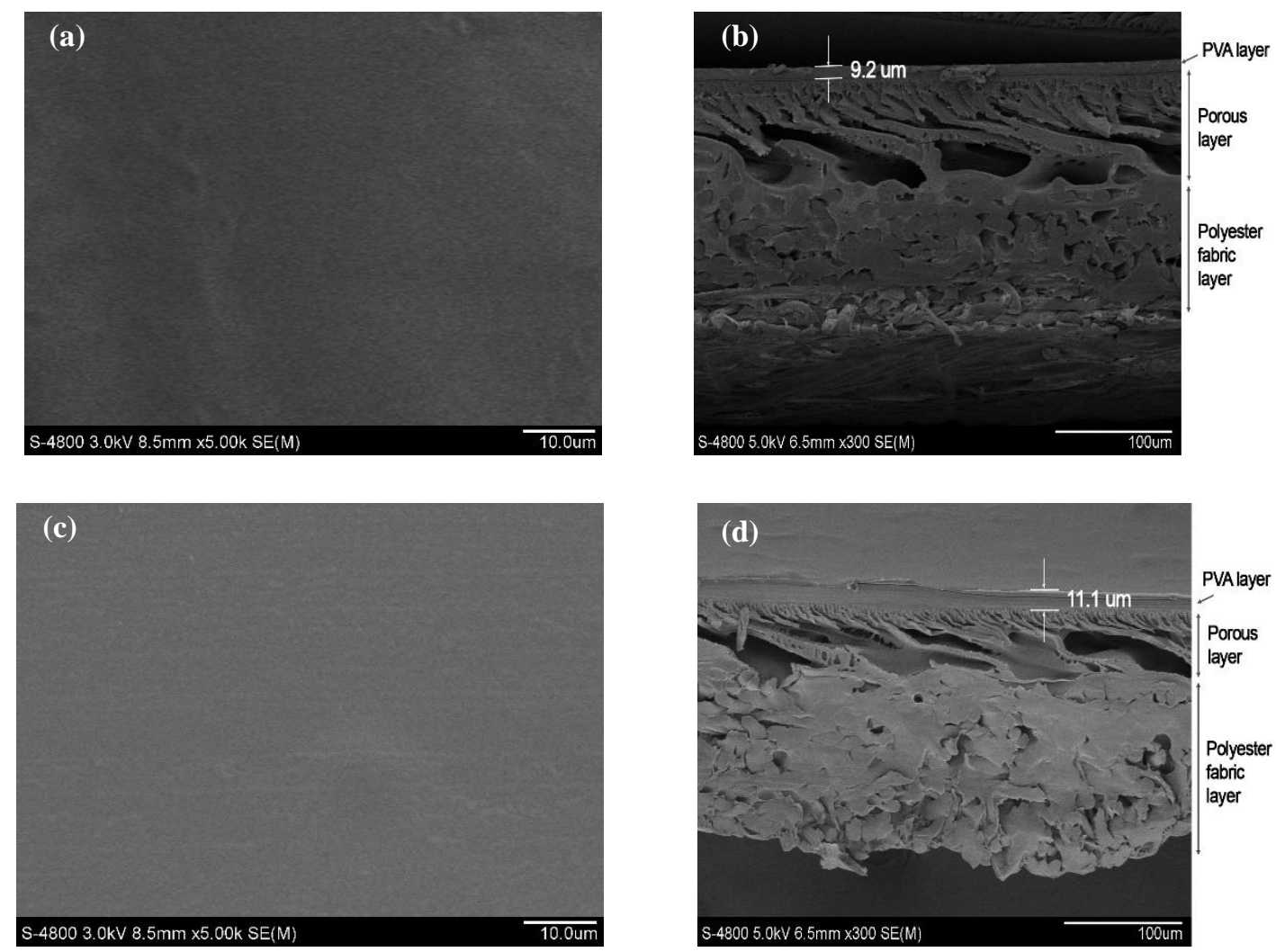

Figure 4. SEM surface and cross-section images of non-crosslinked (a,b) and crosslinked (c,d) membranes

Additionally, the hydrophilicity of the prepared membrane surface was different depended on the chemical structure of crosslinking agents. For crosslinked membranes, the GA-PVA membrane showed the lowest hydrophilicity, while the malic acid-PVA membrane had the highest hydrophilicity due to the additional hydroxyl group on acid malic molecules $[2,3,8]$. The maleic and fumaric acidPVA membranes were less hydrophilic owing to the double bond in in their molecules. From Figure 3, the swelling degree of the prepared membranes was observed to follow the trend of plain PVA > GA-PVA > malic acid-PVA > maleic acid-PVA $>$ fumaric acid-PVA. It would come from steric effect of the various chemical structures of the crosslinking agents. Malic acid exhibited the highest steric hindrance due to the hydroxyl group in its molecule. Both fumaric acid and maleic acid had a carbon double bond on their molecules, but fumaric acid had the trans isomerism in comparison with the cis structure of maleic acid. Hence, the steric hindrance effect of fumaric acid was lower than that of maleic acid [2,3]. Although the GA showed the lowest steric hindrance, the GAPVA membrane exhibited slightly more swelling degree compared to PVA membrane crosslinked with carboxylic acids. It was due to the lower crosslinking temperature of GA-PVA compared to dicarboxylic acid-PVA membrane. Previous studies reported that the crosslinking in 
lower temperature might induce the protonation of function groups of GA, which lessened the etherification and acetalization reactions [4-6,8].

Figure 4. presented the SEM images of the surface and cross-section structure of uncrosslinked and crosslinked PVA membranes. There was no observed difference of surface and cross-section morphology between the virgin and the modified membranes. The derived membranes had a composite structure, involving a dense and uniform PVA film on the top of the PAN porous layer, and the non-woven fabric substrate at the bottom of the membrane. It was observed that macro voids or defects were not found on and in the selective PVA film. Moreover, the interface between the PVA film and PAN support was difficult to discriminate for the crosslinked membrane, implying the good bond formed between the PAN support layer and PVA selective film. The thickness of the derived membranes was approximately 10 $\mu \mathrm{m}$ via maintaining the gap of the casting knife at $70 \mu \mathrm{m}$.

\subsection{Separation performance of the crosslinked PVA membranes}

Figure 5 presented the permeation flux and separation factor of prepared membranes, which was evaluated for the pervaporation dehydration of $80 \mathrm{wt} \%$ ethanol solution at $60{ }^{\circ} \mathrm{C}$. The permeation flux of the derived membrane was observed to decrease in the order of plain PVA $>$ GA-PVA > Malic acid-PVA > maleic acidPVA > fumaric acid-PVA. Meanwhile, the separation factor showed the opposite trend. The plain PVA membrane was easily swelled in aqueous solution during pervaporation test due to the high affinity of the hydroxyl group with water and hence, the permeation flux was high but the selectivity was insignificant. The results showed that the permeation flux of the crosslinked membranes was lower than that of the plain PVA membrane. The crosslinking in the PVA layer resulted in the rigid structure. The rigid structure of the polymer chains had less mobility and hence, the solubility and diffusive ability of the water and ethanol molecules were hindered. Accordingly, the crosslinked membranes obtained a lower permeation flux but higher selectivity. For PVA membrane crosslinked by dicarboxylic acids, the permeation flux and separation factor varied with the chemical structure of the crosslinker. The membrane crosslinked by malic acid showed the highest flux but the lowest separation factor in comparison with that by fumaric and maleic acid due to the higher steric hindrance of hydroxyl functionality of malic acid. Despite having the same carbon double bond, fumaric acid owned trans isomerism with smaller steric hindrance than cis isomerism structure of maleic acid. Therefore, the fumaric acid crosslinked membrane exhibited the lowest flux but the highest separation factor. For crosslinking PVA membrane with GA at ambient temperature, the separation factor was observed to significantly enhance while the flux was declined partially as compared to the plain PVA membrane. 


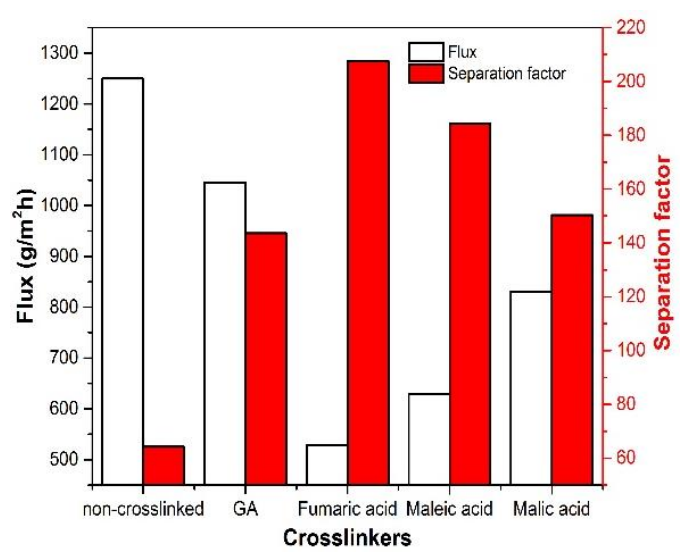

Figure 5. Permeation flux and separation factor of prepared membranes

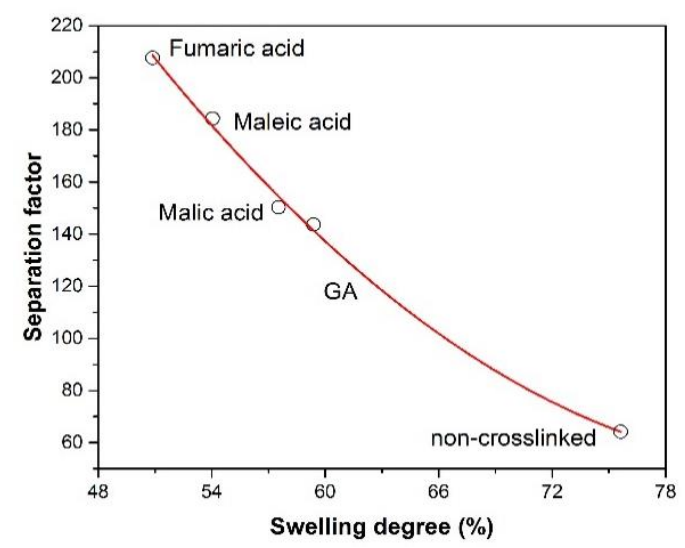

Figure 7. Relationship between swelling degree and separation factor of prepared membranes

From Figure 6 and Figure 7, it was found that the permeation flux and separation factor were closely related to the swelling degree of the derived membrane. The higher swelling degree gave the lower separation factor but the higher flux. Both flux and selectivity were the essential parameters for the pervaporation process. It was observed that there was a tradeoff between the permeation flux and selectivity of the membrane. When the flux increased, the separation factor decreased. Therefore, the term of pervaporation separation index (PSI) was employed for measuring the separation

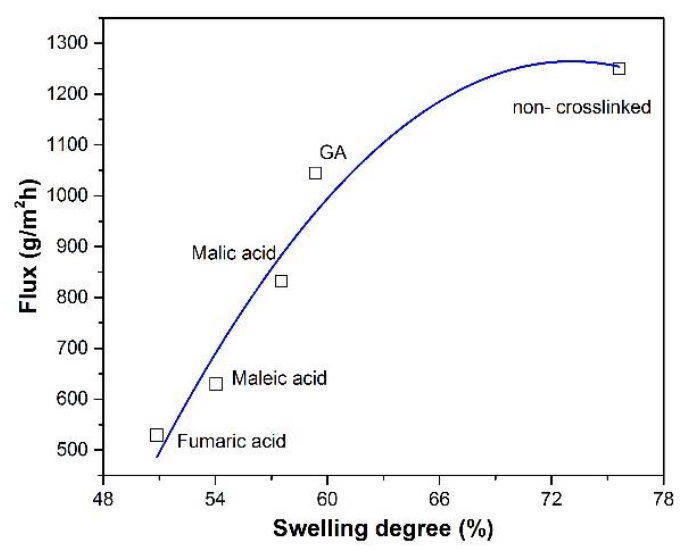

Figure 6. Relationship between swelling degree and flux of prepared membranes

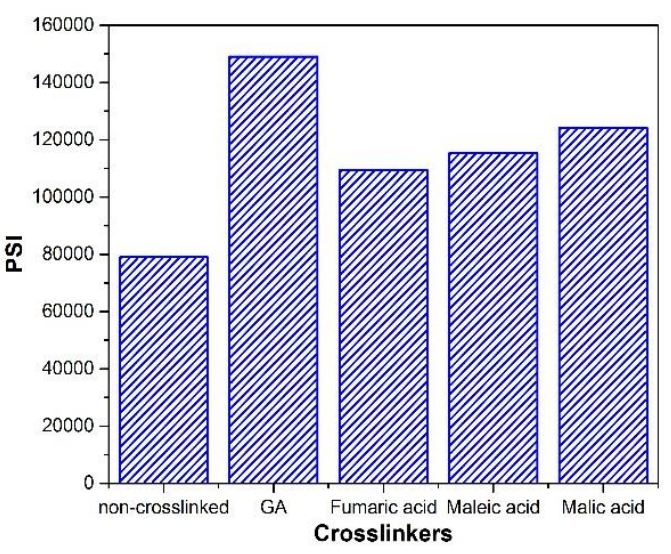

Figure 8. Pervaporation separation factor of noncrosslinked and crosslinked PVA membranes

capability of the pervaporation membrane. The PSI of the prepared membranes were showed in Figure 8. Among the prepared membranes, GA crosslinked membrane exhibited the highest PSI. In comparison, GA was a good crosslinker for modifying membrane due to good flux and good selectivity, while the crosslinking condition was not required high temperature.

\section{CONCLUSIONS}

The PVA membrane crosslinked with various crosslinking agents was successfully prepared by in-situ crosslinking technique. The 
results showed that crosslinking PVA membrane improved the separation performance of the resulting membrane. The chemical structure of the crosslinkers affected the physicochemical properties and separation performance of the crosslinked membrane. Particularly, the swelling degree exhibited a significant relationship with the separation performance of the prepared membrane. Moreover, elevating the crosslinking temperature was observed to improve the selectivity, but decrease the permeation flux of the resulting membrane. Crosslinking PVA membrane with dicarboxylic acids at high temperature was found to achieve higher separation factor but lower flux as compared to that with GA. The GA exhibited as a proper crosslinker for modifying PVA membrane due to good flux and good selectivity, while the crosslinking condition was not required high temperature.

Acknowledgment: The authors gratefully acknowledge the financial support provided by the Ministry of Industry and Trade of the Socialist Republic of Vietnam under Grant 11/HĐ-ÐT.11.14/NLSH.

\section{Làm khan hỗn hợp ethanol-nước bằng phương pháp thẩm thấu bốc hơi sử dụng màng poly(vinyl alcohol) nối mạng}

- Trần Lê Hải

- Vưu Ngọc Duy Minh

- Hoàng Minh Quân

- Nguyễn Thị Nguyên

- Mai Thanh Phong*

Trường Đại Học Bách Khoa, ĐHQG-HCM

\section{TÓM TẮT}

Trong bài báo này, chúng tôi đã tạo ra màng loc compozít trên nền poly(vinyl alcohyol) (PVA) bằng cách phủ một lớp màng chọn lọc PVA đuợc nối mang lên lớp đế xốp polyacrylonitrile (PAN). Phưong pháp nối mạng in-situ được sử dụng để tạo ra màng mỏng PVA nối mạng với bốn tác nhân khâu mạng khác nhau bao gồm glutaraldehyde, axít fumaríc, axít malêíc, axít malíc. Hiệu quả phân tách của màng tạo thành qua các thông số thông luợng nước thẩm thấu, hệ số phân tách được đánh giá bằng quá trình tách nước hốn hợp ethanol-nước với tỷ lệ nồng độ 80/20\% \%l ở $60{ }^{\circ}$ C. Các phuoong pháp đo phổ hồng ngoại FTIR, SEM, đo 
độ trưong nở và đo góc tiếp xúc của màng với nước cất được sủ dụng để đánh giá các đặc tính của màng lọc tạo thành. Kết quả cho thấy các tính chất lý hóa (tính va nước và độ truoong nở) và hiệu quả phân tách của màng chịu ảnh hương bởi cấu trúc hóa học của các tác nhân nối mạng. Ngoài ra, có sự cân bằng giũa thông luợng thẩm thấu và độ chọn lọc của màng tạo thành. Khi thông luợng thẩm thấu qua màng tăng thi độ chọn lọc của màng giảm. Kêt quả của thí nghiệm góp phẩn làm giàu dĩ liệu về phản úng nối mạng của màng PVA, nhằm giúp các nhà khoa học chọn lựa phù hợp các tác nhân nối mạng để biến tính màng thẩm thấu bốc hoi trên nền PVA, úng dụng để tách nước dung dich ethanol.

Tù khóa: poly (vinyl alcohol); nối mạng; màng lọc; thẩm thấu - bốc hơi; tách nước

\section{REFERENCES}

[1]. P. Shao, R.Y.M. Huang, Polymeric membrane pervaporation, Journal of Membrane Science 287 162-179 (2007)

[2]. Brian Bolto, Thuy Tran, Manh Hoang, Zongli Xie, Crosslinked poly(vinyl alcohol) membranes, Progress in Polymer Science 34 969-981 (2009)

[3]. B. Bolto, M. Hoang, Z. Xie, A review of membrane selection for the dehydration of aqueous ethanol by pervaporation, Chemical Engineering and Processing 50 227-235 (2011)

[4]. K.J. Kim, S.B. Lee, N.W. Han, Kinetics of crosslinking reaction of PVA membrane with glutaraldehyde, Korean J. of Chem. Eng. 11(1) 41-47 (1994)

[5]. C.K. Yeom, K.H. Lee, Pervaporation separation of water-acetic acid mixtures through poly (vinyl alcohol) membranes crosslinked with glutaraldehyde, Journal of Membrane Science 109 257-265 (1996)

[6]. V.S. Praptowidodo, Influence of swelling on water transport through PVA-based membrane, Journal of Molecular Structure 739 207-212 (2005)

[7]. J.M. Gohil, A. Bhattacharya, P. Ray, Study on crosslinking of poly (vinyl alcohol), Journal of Polymer Research 13 161-169 (2006)

[8]. F. Peng, Z. Jiang, E.M.V. Hoek, Tuning the molecular structure, separation performance and interfacial properties of poly (vinyl alcohol) - polysulfone interfacial composite membranes, Journal of Membrane Science 368 26-33 (2011) 